\title{
Malgorzata JANicka
}

Uniwersytet Warszawski

\section{Tomasz Pudfocki, „Będziemy dziafać”. Wincenta Tarnawska w służbie niepodległości Polski, Historia Iagellonica, Kraków} 2013, ss. 338

„Będziemy działać” to kolejna praca Tomasza Pudłockiego z cyklu publikacji dotyczących historii społecznej kresów południowo-wschodnich. Autor znów zabiera nas w podróż po Przemyślu przełomu XIX i XX w., czasach burzliwej walki o polskość Kresów i niepodległość Polski. Tym razem w centrum zainteresowania znalazła się Wincenta Tarnawska, choć jak Autor sam przyznał, planował napisanie książki o jej synu Władysławie Tarnawskim, pierwszym polskim tłumaczu dzieł Williama Shakespeare’a. Jest to publikacja prekursorska, jeżeli chodzi o tę postać. Wzmiankowana była ona w książkach dotyczących Przemyśla tego okresu, ale nikt jak dotąd nie podjął się napisania jej biografii. Może dlatego, że było to zadanie wyjątkowo trudne z racji niewielkiej spuścizny pisarskiej. Ślady jej niezwykłej wprost aktywności prześledził Autor na podstawie wspomnień jej współczesnych, doniesień prasowych, sprawozdań z działalności licznych organizacji, w których pracach uczestniczyła, oraz recenzji wydarzeń kulturalnych, jakich była animatorką. Istotnym źródłem były również wspomnienia potomków Wincenty, z którymi Autor kontaktował się osobiście. We wspomnieniach jej współczesnych, szczególnie kobiet, z którymi współpracowała, jawi się ona jako ikona kobiecego ruchu narodowowyzwoleńczego. Autor starał się prześledzić proces przeistaczania się Tarnawskiej z typowej Matki Polki w Matkę Narodu. Do zbudowania charakterystyki skomplikowanej natury Tarnawskiej niezbędne były specyficzne założenia metodologiczne. Wśród nich pierwsze miejsce zajęła metodologia gender, wzbogacona o nurty heroiczny oraz narodowotwórczy kobiet. Niebagatelny wpływ na nakreślenie sylwetki 
Tarnawskiej miały również badania historyczne nad starością, jej percepcją i oddziaływaniem na kształtowanie się stosunków społecznych.

Praca jest wewnętrznie nierówna, wyczuwa się pewną dychotomię. Rozdziały dotyczące społecznej działalności Tarnawskiej na forum publicznym oraz dziejów jej rodziny oparte zostały na rzetelnej kwerendzie prasowo-archiwalnej. Narracja oparta jest na zarejestrowanych faktach historycznych i nie ma potrzeby ich podważania lub reinterpretacji. Natomiast rozdziały poświęcone motywom i głębszemu podłożu psychologicznemu działań Tarnawskiej tworzą konstrukcję dyskusyjną ze względu na z natury rzeczy skomplikowany przedmiot badania. Jeżeli chodzi o religijność bohaterki, jej ascezę i całkowite oddanie się walce o polską tożsamość ludności okręgu przemyskiego oraz poświęcenie się walce o niepodległość, to nie ma co do nich żadnych wątpliwości. Jednak celem Autora było przeanalizowanie funkcjonowania i roli Tarnawskiej w środowisku Przemyśla, przedstawienie wyjątkowości postawy i zachowań typowej przedstawicielki warstwy średniej w rozwijającym się ośrodku miejskim. Chciałoby cię rzec, że cała książka dotyczy nietypowej postawy typowej postaci tej warstwy społecznej w tamtym czasie. Życiorys bowiem Wincenty Tarnawskiej w makroskali nie był wyjątkowy w historii działalności kobiet na przełomie XIX i XX w. oraz ich udziału w walce o przetrwanie polskiej narodowości i odzyskanie niepodległości. Śledząc jej postępowanie na łamach książki Pudłockiego, przez pryzmat przemyskiej mikroskali staje się ona jednak postacią wyjątkową - heroiczną, którą należałoby wpisać w poczet naszych bohaterów narodowych. Skromna i filigranowa, była jednocześnie twarda, uparta i bezkompromisowa. Jej przewodnictwo nad rzeszami galicyjskich kobiet świadczy również o cechach wybitnie przywódczych.

Tylko dzięki swobodnemu poruszaniu się Autora w meandrach interdyscyplinarnej metodologii udało się te zjawiska uchwycić oraz nakreślić portret charakterologiczny postaci wraz z recepcją jej działań z perspektywy współczesnych. Należy podkreślić, że do końca XIX w. Wincenta nie odbiegała swoją aktywnością społeczną od prac kobiet z towarzystwa, w którym się obracała, a pochodziła z jednej z najbardziej wpływowych przemyskich rodzin. Dowód jej nieustępliwego charakteru objawia się historykowi wcześnie, bo już w momencie wyboru kandydata na męża. Młoda Waygartówna, córka burmistrza Przemyśla, postanowiła wyjść za powstańca styczniowego, ubogiego koncypienta adwokackiego Leonarda Tarnawskiego, który niespecjalnie odpowiadał jej rodzicom. Małżeństwo nie było mezaliansem, bo Leonard należał do elity ówczesnej młodej inteligencji, dzieliła ich jednak przepaść finansowo-towarzyska. Tarnawski bardzo szybko okazał się godny wejścia do rodziny. Szkoda, że Autorowi nie udało się wydobyć więcej informacji o młodości Wincenty. Na pierwszym planie pojawia się tylko wcześnie rozwinięty u niej kult powstania styczniowego. Strażniczką pamięci tego wydarzenia i jego bohaterów pozostała do końca życia. Do analizy postaci Tarnawskiej niezbędne było przyjrzenie się Leonardowi, aktywnemu działaczowi politycznemu i społecznemu, wielkiemu patriocie, który wysoko cenił sobie narodowo-niepodległościową aktywność żony. Niestety niewiele informacji o ich wspólnym życiu prywatnym udało się pozyskać. Ze strzępów wyłonił się obraz małżeństwa partnerskiego, prowadzącego dom otwar- 
ty. Małżeństwa o wspólnych celach, w których realizacji wzajemnie się wspierało. Ten wizerunek zmącony jest ich przeciwnymi sympatiami politycznymi oraz metodami działania - Leonard był politykiem narodowej demokracji, natomiast Wincenta popierała piłsudczyków. Pan Tarnawski wolał sprawy i działania najpierw omówić i skrupulatnie zaplanować, jego małżonka - przede wszystkim działać, już i natychmiast, bez zbędnych i przewlekających sprawy dyskusji. W źródłach dom Tarnawskich jest miejscem zawsze pełnym ludzi, zaniedbanym przez panią domu w związku z jej licznymi obowiązkami. Wspomnienia o stosunkach między małżonkami też nie są spójne, z jednej strony mowa jest o panującej między nimi zgodzie, inne źródła dowodzą, że miały miejsce liczne awantury. Niestety Autorowi nie udało się „wniknąc" głębiej w tę relację, a za przyczynę wspomnianych konfliktów uznał tylko różnice w światopoglądach politycznych.

Można przyjąć, że życie Tarnawskiej składało się z dwóch podstawowych etapów. Pierwszy to okres od dzieciństwa do wieku średniego. Ta epoka zakończyła się w momencie usamodzielnienia się dzieci i ich wyjścia z domu. Tarnawska poświęciła ten czas ich wychowaniu i wspieraniu męża w codziennej aktywności społecznej. Autor stwierdza, że jej religijność i granicząca z przesadą asceza objawiły się w momencie, kiedy umarło ich pierwsze dziecko, i pogłębiały się wraz z dorastaniem kolejnych, bardzo zresztą chorowitych. Dla ochrony dzieci poddawała się kolejnym absurdalnym „wyczynom pokutnym”, np. przyrzekła nigdy nie całować syna lub narzucała sobie kolejne posty. Miało to jakoby uchronić jej potomstwo przed przedwczesną śmiercią. Pudłocki stawia tezę, że po śmierci pierwszego dziecka i okresie wychowywania pozostałej bardzo chorowitej dwójki Tarnawska popadła w hiperreligijność i ascezę. Po usamodzielnieniu się dzieci przeniosła swoje zachowania i modlitwy na troskę o ojczyznę.

Jej „drugie życie” charakteryzowało się wzmożoną działalności społeczną. To okres, kiedy opuściła Towarzystwo Szkoły Ludowej i założyła Związek Polek, do którego wkrótce przyłączyło się kilkaset kobiet. Na Kresach powstała organizacja zrzeszająca kobiety $\mathrm{z}$ wszystkich warstw społecznych, zwłaszcza zaś aktywizowała do działania mieszkanki wsi. Pozyskała dla swojej organizacji sympatię wiejskich nauczycielek, w swej pracy przekazujących ducha polskości i świadomości narodowej nowym pokoleniom. Ta działalność Tarnawskiej nie do końca była zrozumiała dla współczesnych. Krytykowano ją za propagowanie sufrażyzmu. Na pierwszy rzut oka można było tak uważać; do podobnego wniosku mógłby dojść nieuważny badacz jej poczynań. Sufrażystki walczące o prawa obywatelskie dla kobiet prowadziły działalność polityczną, a od tej Tarnawska zupełnie się odcinała. Nie wchodziła w dyskusje nad prawami poszczególnych płci, natomiast z dużym prawdopodobieństwem można wysnuć wniosek, że jej zdaniem kobiety i mężczyźni mieli oczywiste prawo do równego decydowania o losie swojej ojczyzny i pracy na rzecz jej niepodległości.

Wzmożona działalność publiczna Tarnawskiej w tym okresie życia spowodowała również rozluźnienie się jej więzi rodzinnych. Oboje z mężem, niezwykle zajęci sprawami publicznymi, nie mieli czasu dla siebie. Najważniejsza jednak w tym 
wszystkim była wspólnota ich działań i to ona do końca życia Leonarda będzie ich bezdyskusyjnie łączyła.

Najciekawsze fragmenty książki to te, w których Autor analizuje sposób kreowania własnego wizerunku przez Tarnawską. Zgadzam się z tezą, że był on androgyniczny. Wincenta po wypełnieniu swojej roli jako matki i żony, w okresie menopauzy postanowiła zrealizować swoje osobiste potrzeby. Już wcześniej przywdziała czarną suknię i złożyła przed Bogiem obietnicę, że w takim stroju pozostanie do końca swoich dni. Niemodna i mało wyzywająca, ukryła swoją seksualność, wyzbyła się atrybutów kobiecości. Jednocześnie, wraz z coraz szerszym zakresem prowadzonej działalności, zaczęła wyraźniej okazywać takie cechy jak nieustępliwość, czasami nawet bezwzględność w dążeniu do celu, samodzielność i bezkompromisowość (szokowała współczesnych publiczną krytyką przekonań politycznych męża), czyli przymioty wybitnie męskie. Ten wizerunek szczególnie przydał się Tarnawskiej w okresie I wojny światowej, kiedy granice między tym, co kobiece i męskie, zacierały się. Przenoszenie broni, ukrywanie tajnych archiwów wojskowych, organizowanie zaopatrzenia dla armii, aprowizacja poszkodowanych $\mathrm{w}$ wyniku wojny, działalność w nielegalnych organizacjach niepodległościowych, pobudzanie ducha walki w żołnierzach w sytuacjach trudnych, czasami nawet beznadziejnych - wszystkie te czynności świadczą o graniczności Wincenty, przenikaniu się w jej życiu czynności przypisywanych mężczyznom i kobietom. Szczególną słabość Tarnawskiej do Ireny Benschówny uważa Autor za objaw niedosytu i braku satysfakcji z własnych dokonań, jak gdyby Wincenta widziała w Benschównie siebie sprzed lat. Młoda sanitariuszka wypełniała zadania, na które 60-letnia już Tarnawska nie mogła sobie pozwolić. O słabości tej świadczy również wystąpienie przeciwko prośbie matki tragicznie zmarłej Benschówny, która poprosiła przemyślan o pomoc w przeniesieniu zwłok córki do rodzinnej Wielkopolski. Tarnawska przekonała zrozpaczoną matkę, że miejsce jej córki jest w Przemyślu, i obiecała postawić na jej grobie pomnik. Zbieranie funduszy na ten cel zajęło Wincencie 10 lat i jest kolejnym dowodem ogromnego przywiązania i potrzeby uhonorowania Ireny.

Uprzywilejowana pozycja społeczna Tarnawskiej oraz wpływy jej ojca i męża (liczne znajomości i dojścia) pomogły jej z pewnością w osiąganiu założonych celów, a tym samym wzbudzaniu powszechnego szacunku. Również pojawiająca się gdzieniegdzie krytyka jej działań i postępowania formułowana była w taki sposób, by nie urazić jej osoby. „Podpadnięcie” bardzo wpływowej staruszce mogło przynieść poważne konsekwencje jej przeciwnikom. Autor niestety nie dość jasno wytłumaczył mechanizmy działania tej krytyki. Z książki wynika, że socjaliści w obawie przed rosnąca pozycją Wincenty starali się ją zdezawuować, wykorzystując do tego jej męża. Jest to jeden $\mathrm{z}$ wątków, któremu brak rozwinięcia.

Wydawało się, że ponad wszelkimi podziałami Tarnawska w końcu zaliczona została w poczet bohaterów narodowych. Tuż przed wybuchem II wojny światowej, jesienią 1938 r., mianowano ją patronką III Państwowego Gimnazjum Żeńskiego w Przemyślu. Nie wiadomo, czy ta inicjatywa została usankcjonowana przez władze centralne. Autor stwierdza, że tym gestem ciesząca się sympatią Tarnawskiej sanacja 
chciała wykorzystać jej postać dla podreperowania swojego wizerunku. Szkoda, że ten wątek też nie doczekał się rozwinięcia, a pozostawiony został tylko jako prawdopodobna wersja wytłumaczenia tego zjawiska.

W okresie II Rzeczpospolitej Związek Polek stał się organizacją anachroniczną. Tarnawska jeszcze organizowała pomoc dla weteranów, wystawy i rocznice narodowych świąt. Ale powoli odsuwała się od działalności publicznej, z jednej strony prawdopodobnie ze względu na wiek, z drugiej przez konieczność zajmowania się schorowanym mężem, po którego śmierci już zupełnie ograniczyła swą aktywność.

W przypadku „Będziemy działać” mamy do czynienia z bohaterką, która jest postacią z pogranicza religijnego i narodowościowego. Wzięcie pod uwagę wszystkich tych elementów jest ważne dla całości obrazu. W tej pracy metodologia gender zajęła miejsce decydujące, jest to jednocześnie największe pole dla krytyki tej pracy. Tomasz Pudłocki, specjalista w zakresie historii Przemyśla przełomu XIX i XX w., podjął się wielce trudnego zadania, przedstawienia postaci, która przez prawdziwą skromność unikała rozgłosu wokół swojej osoby. Dlatego, opisując jej charakter, motywy postępowania, kreację wizerunku, Autor wielokrotnie używał sformułowania „prawdopodobnie”. I w tych miejscach książka jest najbardziej dyskusyjna, a jednocześnie najbardziej inspirująca. Na przykład fragment, w którym Autor stwierdził, że idąc za wzorem św. Jadwigi Śląskiej, Wincenta odmówiła mężowi kontaktów seksualnych. A może nie wpływ świętej zdecydował o takiej postawie, a chęć ukoronowania swojego androgynicznego wizerunku? $\mathrm{Z}$ innej strony, czytając o kolejnych aktach ascezy, podejmowania się wciąż nowych postów, odbierania sobie wszelkiej przyjemności i rozrywki przez Tarnawską, narzuca się myśl, że cierpiała na nerwicę natręctw. Za tym ostatnim przemawiałyby wzmożone zachowania ascetyczne Tarnawskiej w sytuacjach wyjątkowego stresu. Oczywiście z braku źródeł nie da się tych zagadnień ostatecznie roztrząsnąć, ale zabrakło w niektórych fragmentach książki kilku opcji interpretacji zachowań Wincenty.

Po lekturze „Będziemy działać” rzuca się w oczy fakt, że Autor lubi opisywaną postać. Bardzo dobrze dobrana metodologia nie dałaby takich efektów, gdyby do sytuacji kreowanych przez los i nią samą podszedł bez empatii. Jednocześnie nie zabrakło miejsca dla krytycznego ujęcia osobowości i motywów działań Tarnawskiej. Przy innym podejściu do analizy jej osobowości i działalności powstałaby laurka na jej cześć. Pudłocki wydobył dla czytelnika postać z krwi i kości, uwikłaną w trudne warunki społeczno-historyczne. Po lekturze tej książki pozostaje niedosyt. Dla historyków może stać się polem do ciekawej dyskusji nad skomplikowaną strukturą badania historii społecznej w mikroskali i korzyści z zastosowania różnych nurtów badań historycznych do wydobycia skrawka przeszłości. Dla czytelnika nieuwikłanego $\mathrm{w}$ metodologię i nurty badań historycznych jest to solidnie opracowany fragment historii naszego kraju, podany w przystępny i rzetelny sposób.

I jeszcze jedno. Autorowi nie udało się ustalić, czy i jaki udział w dyskusji nad emancypacją kobiet miał Związek Polek. Tym niemniej wydaje się, że Wincenta Tarnawska swoim działaniem inspirowała, a zaangażowaniem w prace związku aktywizowała do udziału w życiu publicznym kobiety, które wypełniły już przepisane 
im powszechnie obowiązującą umową społeczną role. W tym celu posługiwała się między innymi cyklami wykładów historycznych o wybitnych Polkach. Po przeczytaniu tej książki trudno oprzeć się wrażeniu, że Pudłocki napisaniem jej i przedstawieniem szerszej publiczności postaci Wincenty wpisał się bezwiednie w jeden z jej nurtów działania. Wszak zagadnienie niewielkiego udziału kobiet w życiu publicznym i problem ich aktywizacji, szczególnie $\mathrm{w}$ wieku podeszłym, i dziś nie stracił na aktualności. 